\title{
The Influence of Profitability, Corporate Social Responsibility and Firm Size on Firm value (Studies on Issuers in the Automotive Sub-Sector and Components in 2014 - 2018)
}

\author{
Achmad Dwi Pratomo ${ }^{1}$, Sudjono ${ }^{2}$ \\ ${ }^{1}$ Achmaddwi1798@gmail.com, ${ }^{2}$ Sudjono@mercubuana.ac.id \\ ${ }^{1}$ Universitas of Mercu Buana, Jakarta and 11650, Indonesia \\ ${ }^{2}$ Universitas of Mercu Buana, Jakarta and 11650, Indonesia
}

\begin{abstract}
This study aims to analyze the effect of profitability, corporate social responsibility and company size on company value (study on the automotive sub-sector issuers and components in 2014 - 2018). The population in this study were 13 companies. The sample in this study were 10 companies. The sample in this study was selected using purposive sampling method and testing using panel data regression analysis. The results in this study indicate that profitability (ROA) has a positive and significant effect on firm value (PBV), Corporate Social Responsibility (CSRI) has a negative and insignificant effect on firm value (PBV). and Company Size (SIZE) has a negative and insignificant effect on firm value (PBV).
\end{abstract}

Keywords: Company Value (PBV), Profitability (ROA), Corporate Social Responsibility (CSRI), Company Size (SIZE).

\section{Introduction}

A good company must be able to control both financial and non-financial potentials in increasing company value for the company's long-term existence. To see the value of the company, you can find an overview of the company's financial position. And to analyze the income statement to find out the results of the company. Financial data can be analyzed further so that definite information will be obtained and can support the decisions that will be made.

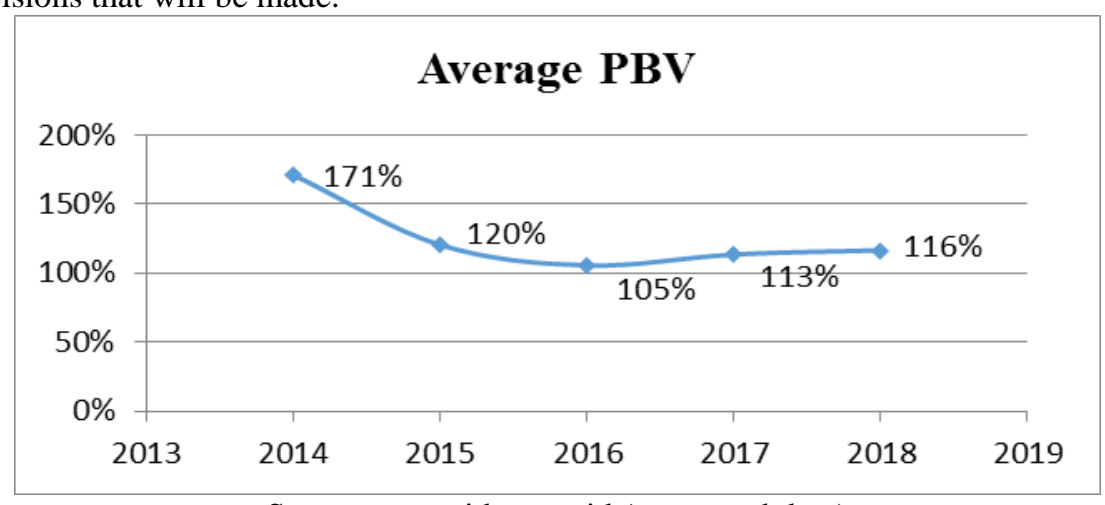

Source: www.idx.com.id (processed data)

Figure 1 Average Price Book Value of Companies in the Automotive Sub-Sector and Components in 2014-

2018 
Based on the figure, it can be seen that the average Price Book Value in the automotive and component sub-sector companies has increased and decreased but tends to have a descent from year to year. In 2014 the company's Price Book Value was 171\%, then the Price Book Value decreased by 120\%, while in 2016 the Price Book Value decreased by 105\%, in 2017 the Price Book Value increased by $113 \%$ and in 2018 Price Book Value slightly increased to be $116 \%$.

Data on price book value with sales, seems to contribute in assessing the ups and downs of company value, because higher sales of the company will attract investors to invest in the company. Following below is the development of sales in the automotive sub-sector industrial companies and their components.

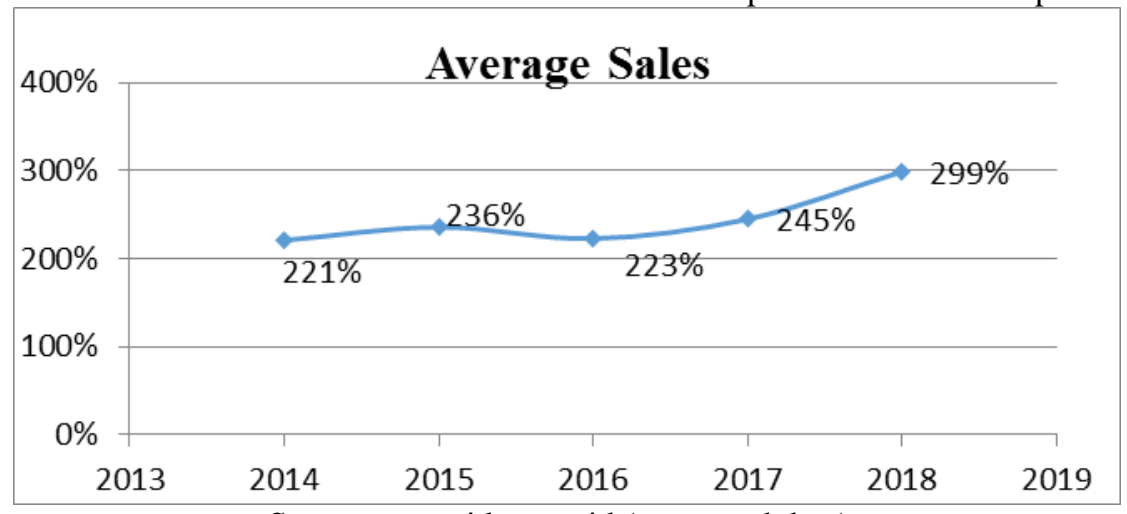

Source: www.idx.com.id (processed data)

Figure 2 Average Sales of Automotive Sub-Sector Companies and Components in 2014-2018

Based on the picture above, it can be seen that the average sales of companies in the automotive and component sub-sectors have fluctuated but tend to increase, which is supported by the company's sales from year to year. In 2014 the company's sales amounted to $221 \%$, then increased in sales value by $236 \%$, while in 2016 sales decreased by $223 \%$, in 2017 sales increased by $245 \%$ and in 2018 sales continued to increase to $299 \%$. This phenomenon shows that there is a fluctuation in the value of the company in the automotive subsector companies and their components which have increased and decreased.

Thus, it can be seen that the increase in sales is not followed by a decrease in Price Book Value. With company growth that can measure the value of the company is a desirable expectation for both internal and external parties of the company. This growth is expected to provide positive aspects for the company, especially with the presence of company value.

In Chasanah and Adhi's (2017) research, the results show that profitability, capital structure have a significant positive effect on firm value and liquidity does not have a significant negative effect on firm value. However, according to Putri and Mardenia's research (2019) The results show that Good Corporate Governance has a significant positive effect on firm value, while Corporate Social Responsibility, profitability does not have a significant effect on firm value and firm size has a negative effect on firm value.

In Widyantari and Yadnya's (2017) research, the results show that profitability has a significant positive effect on firm value, firm size has no significant positive effect on firm value and capital structure has a negative and insignificant effect on firm value. But in the research of Wahyuni and Hadi Santoso (2019) profitability and corporate social responsibility have a negative and insignificant effect on firm value while company size has a negative and significant effect on firm value.

\section{Literature Review \\ Signalling Theory}

Signaling theory is one of the pillar theories in understanding financial management. In general, signals can be interpreted as signals made by companies to investors. These signals can take the form of, either directly observable or that require more in-depth study to find out. Signals conveyed through corporate action can be in the form of positive and negative signals (Fauziah 2017). 
Signalling theory indicates that an organization continues to strive to show signals that can be positive information to potential investors through disclosure in a company's financial statements, a positive signal from an organization is expected to get a positive response from the market, it can provide an advantage. which is competitive for a company, and can provide a high enough value for the company (Lestari and Sapitri, 2016).

\section{Stakeholder Theory}

Stakeholder theory is a collection of policies and practices related to stakeholders, values, compliance with legal provisions, community and environmental respect, and the commitment of the business world to contribute to sustainable development. Based on the explanation of this stakeholder theory, the company not only operates for its own interests, but must provide benefits for other stakeholders such as (shareholders, creditors, consumers, suppliers, government, society, analysis and other parties). One of the strategies that companies use to maintain relationships with their stakeholders is the disclosure of financial, social and environmental information. This disclosure is expected that the company will be able to meet the information needs needed and be able to manage stakeholders so that they can get support from stakeholders who have an effect on the company's survival (Wati, 2019).

\section{Firm Value}

Firm value will describe the performance and condition of the company in the past, today and its prospects for the future period. Business competition requires all companies to make various efforts to achieve the desired goals (Astuty, 2017). Firm value is the investor's perception of the company, which is often associated with stock prices. The value of the company, which is formed through the stock market indicator, is strongly influenced by investment opportunities. Investment spending provides a positive signal from investment to managers about the company's future growth, thereby increasing the stock price as an indicator of firm value. High stock prices make the company value also high (Brealey et al, 2007: 46).

\section{Firm Size}

According to Prasetyorini (2013: 186) firm size is a scale where the size of the company can be classified according to various ways, including total assets, $\log$ size, stock market value, and others. The size of the company is seen from the total assets owned by the company that can be used for company operations. The greater the total assets owned by a company, the greater the size of the company. The bigger the assets, the greater the invested capital, while the more sales, the more debt turnover in the company (Sujarweni, 2015: 211).

\section{Corporate Social Responsibility}

Corporate Social Responsibility can be said to be a continuous commitment from the business community, to behave ethically and contribute to economic development while improving the quality of life of employees and their families, as well as the local community and the wider community in general (wati 2019). Corporate Social Responsibility is a form of corporate social responsibility to the company (community) around it which is a series of active company activities in the midst of society and all stakeholders with an interest in developing quality towards a better direction in various dimensions of life (Yusuf 2017).

\section{Profitability}

Profitability ratio is a ratio to assess the company's ability to seek profit or profit in a certain period. This ratio also provides a measure of the level of management effectiveness of a company as indicated by the profit generated from sales or from investment income (Kasmir, 2017: 114). According to Putranto (2014), profitability has an important meaning in an effort to maintain its survival in the long term, because 
profitability shows whether the business entity has good prospects in the future or not. Thus, every business entity will always try to increase its profitability, because the higher the level of profitability of a business entity, the more secure the continuity of the business entity is.

\section{Research Methods}

This research is a quantitative study using a causal research model with several independent variables on one dependent variable. The independent variables used are profitability, corporate social responsibility and firm size. Meanwhile the dependent variable uses firm value. In this study, the influence of profitability, corporate social responsibility and firm size on firm value will be sought.

Table 1 Operational Variables

\begin{tabular}{cccc}
\hline Variable & Proxy & Measuring Instrument & Scale \\
\cline { 1 - 3 } Firm Value & $\begin{array}{c}\text { Price to Book } \\
\text { Value }\end{array}$ & PBV $\frac{\text { Harga per lembar saham }}{\text { Nilai Buku per lembar saham }}$ & Ratio \\
\cline { 1 - 3 } Profitability & $\begin{array}{c}\text { Return on Asset } \\
\text { (ROA) }\end{array}$ & $\frac{\text { laba bersih }}{\text { total asset }}$ & Ratio \\
\cline { 1 - 2 } $\begin{array}{c}\text { Corporate } \\
\text { Social } \\
\text { Responsibility }\end{array}$ & $\begin{array}{c}\text { Corporate Social } \\
\text { Responsibility } \\
\text { Index } \\
\text { (CSRI) }\end{array}$ & CSRIj $\frac{\sum \text { Xinj }}{\text { nj }}$ & Ratio \\
\hline Firm Size & Firm size & Firm Size $=$ Log Natural Total Aset & Ratio \\
\hline
\end{tabular}

Table 2 Research Sample

\begin{tabular}{|c|c|c|}
\hline No & Comoany Name & Code \\
\hline 1 & PT. Astra Internasional Tbk & ASII \\
\hline 2 & PT. Astra Otoparts Tbk & AUTO \\
\hline 3 & PT. Gajah Tunggal Tbk & GJTL \\
\hline 4 & PT. Indomobil Sukses Internasional Tbk & IMAS \\
\hline 5 & PT. Indospring Tbk & INDS \\
\hline 6 & PT. Prima Alloy Steel Universal Tbk & PRAS \\
\hline 7 & PT. Selamat Sempurna Tbk & SMSM \\
\hline 8 & PT. Indo Kordsa Tbk & BRAM \\
\hline 9 & PT. Goodyear Indonesia Tbk & GDYR \\
\hline 10 & PT. Multistrada Arah Sarana Tbk & MASA \\
\hline
\end{tabular}

The source of this data is obtained from the financial reports of the automotive sub-sector during the research period from 2014-2018. The data collection technique in this study was carried out by using the documentation method. The documentation method, namely the documentation of secondary data, is by collecting, recording, and reviewing documents regarding the financial data of automotive sub-sector companies during the research period from 2014-2018 which are listed on the Indonesia Stock Exchange by accessing the official website of the Indonesia Stock Exchange (BEI ) namely: www.idx.co.id. Conduct literature review, exploration and review of various literature related to research. The method used in analyzing the data in this study will be compiled with the IBM SPSS statistics application. 


\section{Results and Discussion}

The following are the results of the Anova F test:

Table 3 Anova F Test

\begin{tabular}{|r|r|}
\hline F & Sig. \\
\hline 57.746 & $.000^{\mathrm{b}}$ \\
\hline
\end{tabular}

Source: Processed data with SPSS v.25 (2020)

Based on this, it can be seen that the calculated $F$ value in this study is 57,746 with a significance level of 0,000 . The $\mathrm{F}$ value will be compared with the $\mathrm{F}$ table value. The $\mathrm{F}$ table value of 3.20 is measured with degrees of freedom df $1=(\mathrm{k}-1)=3-1=2$ and df $2=(\mathrm{n}-\mathrm{k})=50-3=47$. Where $\mathrm{k}=$ the number of independent variables and $\mathrm{n}=$ number of samples. Furthermore, the results obtained that $\mathrm{F}$ count is greater than $\mathrm{F}$ table $(57,746>3 ., 0)$ and the significance value is less than $0.05(0.000<0.05)$. So it can be said that the regression model in this study is feasible to predict the effect of the variable Profitability (ROA), Corporate Social Responsibility (CSRI) and Company Size (Ln Total Asset) on Firm Value (PBV).

Table 4 Multiple Linear Regression Analysis

\begin{tabular}{ll|r|r} 
& \multicolumn{2}{c|}{ Unstandardized Coefficients } & Standardized Coefficients \\
Model & B & Std. Error & Beta \\
\hline 1 (Constant) & 1.291 & 0.668 & \\
\hline ROA & 0.145 & 0.017 & 0.805 \\
\hline CSRI & -0.830 & 1.493 & -0.053 \\
\hline LN TOTAL ASET & -0.025 & 0.021 & -0.141 \\
\hline
\end{tabular}

Source: Processed data with SPSS v.25 (2020)

Panel data analysis is used to measure the presence or absence of influence between profitability (X1), corporate social responsibility (X2), company size (X3), as an independent variable (free) on firm value (Y) as the dependent variable (dependent). Based on table 4.9, it is known that the results of multiple linear regression analysis, it can be obtained that the panel data regression equation in this study is as follows:

Firm Value $=1,291+0,145 \mathrm{ROA}_{\mathrm{it}}-0,830 \mathrm{CSRI}_{\mathrm{it}}-0,025 \mathrm{LN}$ TOTAL ASSET $\mathrm{it}_{\mathrm{it}}$

The regression equation above has the following meanings:

1. A constant of 1.291 states that if the variable value of Profitability (ROA), Corporate Social Responsibility (CSRI) and Company Size (Ln Total Asset) is equal to zero (0), then the total value of the firm value is 1.291.

2. Profitability (ROA) has a regression coefficient with a positive sign of 0.145 which means that ROA has a positive effect on Firm Value. This shows that if there is an increase of $1 \%$ in ROA, assuming the other independent variables are constant, it will be followed by an increase in Firm Value of $0.145 \%$.

3. Corporate Social Responsibility (CSRI) has a regression coefficient with a negative sign of $(-0.830)$, which means that CSRI has a negative effect on Firm Value. This shows that if there is an increase of $1 \%$ in CSRI, assuming the other independent variables are constant, it will be followed by a decrease in Firm Value of $(-0.830 \%)$.

4. Firm Size (Ln Total Asset) has a regression coefficient with a negative sign of (-0.025), which means that firm size has a negative effect on firm value. This shows that if there is an increase of $1 \%$ in Company 
Size, assuming the other independent variables are constant, it will be followed by a decrease in Firm Value of $(-0.025 \%)$.

Table 5 Hypothesis Test ( $\mathrm{t}$ Test)

\begin{tabular}{lr|r}
\hline & \multicolumn{1}{c}{$T$} & \multicolumn{1}{c}{ Sig. } \\
\hline 1 (Constant) & 1.932 & 0.060 \\
\hline ROA & 8.531 & 0.000 \\
\hline CSRI & -0.556 & 0.581 \\
\hline LN TOTAL ASET & -1.206 & 0.234 \\
\hline
\end{tabular}

Source: Processed data with SPSS v.25 (2020)

Based on table 5 above, testing the Profitability variable (ROA), Corporate Social Responsibility (CSRI) and Company Size (Ln Total Asset) to Firm Value (PBV) results in:

1. The Effect of Profitability on Firm Value (H1)

Based on the results of the $t$ test in table 5, it can be seen that ROA has a $t$ count of 8.531 with a significant value of 0.000 . Meanwhile, $t$ table can be found using $n-k-1$ degrees of freedom. Where $n$ is the number of samples, while $\mathrm{k}$ is the number of independent variables. So, $(\mathrm{Df}=50-3-1=46)$ and using a level of confidence of $5 \%(\alpha=0.05)$, so that $t$ count is $8.531>t$ table is 1.67866 and the significant level is $0.000<0.05$. Therefore the hypothesis result is $\mathrm{H} 1_{\mathrm{a}}$ is accepted and $\mathrm{H} 1_{0}$ is not accepted. So it can be concluded that Profitability has a positive and significant effect on Firm Value.

In this study, ROA (Return On Asset) has a positive and significant effect on Firm Value. The results of this study are related to research conducted by Sabrin et al. (2016), Setiyowati, Herni (2018), Novitasari, dwi \& Abdul, Muhammad Aris (2019), Sakdiah (2019) and Ningsih \& Sari (2019) said that profitability has a positive and significant effect on firm value. However, it is not related to the research conducted by Oktrima, Bulan (2017) and Mareta \& Yanti (2019) which states that profitability has a negative and insignificant effect on firm value.

2. The Influence of Corporate Social Responsibility on Company Value (H2).

Based on the results of the $t$ test in table 5, it can be seen that CSRI has a t count of -0.556 with a significant value of 0.581 . Meanwhile, $t$ table can be found using $n-k-1$ degrees of freedom. Where $n$ is the number of samples, while $\mathrm{k}$ is the number of independent variables. So, $(\mathrm{Df}=50-3-1=46)$ and using a confidence level of $5 \%(\alpha=0.05)$, so that $t$ count $-0.556<t$ table 1.67866 and a significant level of $0.581>$ 0.05 . Therefore the hypothesis result is that $\mathrm{H} 2_{0}$ is accepted and $\mathrm{H} 2_{\mathrm{a}}$ is not accepted. So it can be concluded that Corporate Social Responsibility has a negative and insignificant effect on Company Value.

In this study, CSRI (Corporate Social Responsibility Index) has a negative and insignificant effect on Company Value. The results of this study are related to research conducted by Ardimas, Wahyu \& Wardoyo (2014) and Hafez, H. M. (2016) which states that CSR has a negative and insignificant effect on firm value. But it is not related to research conducted by Puspaningsih, Abriyani \& Putri, Isna Rahmawati (2012), Putri, Dea Ayu et al (2017), Eddy \& Veronica (2018), Rahayu \& Anggraeni (2019) and Tunpornchai \& Hensawang (2018) that CSR has a positive and significant effect on firm value. 
3. The Effect of Firm Size on Firm Value (H3)

Based on the results of the $t$ test in Table 5, it can be seen that the LN TOTAL ASSET has a t count of -1.206 with a significant value of 0.234 . Meanwhile, $t$ table can be found using $n-k-1$ degrees of freedom. Where $\mathrm{n}$ is the number of samples, while $\mathrm{k}$ is the number of independent variables. So, $(\mathrm{Df}=50-3-1=46)$ and using a confidence level of $5 \%(\alpha=0.05)$, so that $t$ count $-1.206<t$ table 1.67866 and a significant level of $0.234>0.05$. Therefore the hypothesis result is that $\mathrm{H} 3_{0}$ is accepted and $\mathrm{H} 3_{\mathrm{a}}$ is not accepted. So it can be concluded that firm size has a negative and insignificant effect on firm value.

In this study, LN TOTAL ASSET has a negative and insignificant effect on Company Value. The results of this study are related to research conducted by A. Kadim \& Nardi Sunardi. (2019) Company size has a negative and insignificant effect on Firm Value. However, it is not related to research conducted by S, Setiadharma \& M, Machali (2017), Julian, Raja Lovianda \& Ibrahim, Mariaty (2018), Meygriza, Cludia Dolontelide \& Wangkar, Anneke (2019), Sondakh (2019) and Bestariningrum ( 2015) says that company size has a positive and significant effect on firm value.

\section{Conslusion}

Based on the results of data analysis and discussion that has been carried out, the following research conclusions can be drawn:

1. Profitability (ROA) has a positive and significant effect on firm value. Companies that have high company value and usually seen from their profitability or company value will be able to attract more investors and high investment opportunities will provide more benefits for the company because investors will say that the company is healthy and worthy of being an investment.

2. Corporate Social Responsibility (CSRI) has a negative and insignificant effect on Company Value. This is because the disclosure of a company's Corporate Social Responsibility does not necessarily increase the value of the company. Because it often happens that what is carried out in a company's Corporate Social Responsibility does not match what the local community wants, so that what the company does has not received a good response from the surrounding community.

3. Company size (LN TOTAL ASSET) has a negative and insignificant effect on Firm Value. This means that company size is not a consideration for investors in investing because the size of the company is not influenced by the size of the company value.

\section{References}

Ardimas, Wahyu \& Wardoyo. (2014). Pengaruh Kinerja Keuangan dan Corporate Social Responsibility Pada Bank Go Public yang Terdaftar Di BEI". BENEFIT Jurnal Manajemen dan Bisnis, Vol 18, Nomor 1, Juni 2014, Halaman 57-66.

Astuty, P. (2017). The influence of fundamental factors and systematic risk to stock prices on companies listed in the Indonesian stock exchange. European Research Studies Journal, 20(4), 230-240.

Ayu, Dea Putri \& A. A. Gede Suarjaya.(2017). Pengaruh Profitabilitas Terhadap Nilai Perusahaan Dengan Corporate Social Responsibility Sebagai Variabel Mediasi Pada Perusahaan Pertambangan. E-Jurnal Manajemen Unud. Vol 6, No 2. ISSN: 2302-8912.

Brealey, Myers, \& Marcus. (2007). Dasar- dasar Manajemen Keuangan Perusahaan. Edisi kelima. Jakarta: Erlangga.

Chasanah, Nur A. \& Adhi, Kartika D. (2017). Profitabilitas, Struktur Modal dan Likuidiitas Pengaruhnya terhadap Nilai Perusahaan Pada Perusahaan Real Estate yang Listed di BEI Tahun 2012-2015 Fokus 
Ekonomi Vol. 12 No.2 Desember (2017) : 131 - 146.

C.M.Dolontelide \& A.Wangkar. (2019). Pengaruh Sales Growth dan Firm Size Terhadap Nilai Perusahaan Pada Perusahaan Makanan dan Minuman Yang Terdaftar Di Bursa Efek Indonesia. Jurnal Emba: Jurnal Riset Ekonomi, Manajemen, Bisnis dan Akuntasi. Vol.7 No.3 Juli (2019), Hal.3038-3042.

Eddy Winarso \& Veronica Christina M.P. (2018). The Influence Of Profitability To The Company Value With Corporate Social Responsibility As A Variable Moderation.

Fauziah, F. (2017). Kesehatan Bank, Kebijakan Dividen dan Nilai Perusahaan: Teori dan Kajian Empiris. Pustaka Horizon.

Hafez, H. M. (2016). Corporate social responsibility and firm value: an empirical study of an emerging economy. Journal of Governance and Regulation, Vol.5(4), 40-53. https://doi.org/10.22495/jgr_v5_i4_p3

Herni Setiyowati, (2018) Pengaruh Ukuran Perusahaan, Profitabilitas dan Leverage terhadap Nilai Perusahaan (Studi Pada Perusahaan yang Listing di Jakarta Islamic Index Tahun 2013-2016). Skripsi thesis, IAIN.

Ina Wahyuni \& Bambang Hadi Santoso (2019).” Pengaruh Pengungkapan CSR, Profitabilitas dan Ukuran Perusahaan terhadap nilai Perusahaan Sektor Pertaanian di BEI. Jurnal Ilmu dan Riset Manajemen : Volume 8, Nomor 3, Maret (2019) e-ISSN: 2461-0593.

Isti Rahayu \& Desti Anggraeni (2019)." Corporate Governance, Corporate Social Responsibility and Firm Value: Economic Value Added as the Intervening Variable”. Proceeding of The 3rd International Conference on Accounting, Business \& Economics (UII-ICABE 2019).

Kadim, A., Sunardi., N. (2019). Pengaruh Profitabilitas ,Ukuran Perusahaan Terhadap Leverage Implikasi Terhadap Nilai Perusahaan Cosmetics and Household yang terdaftar di Bursa Efek Indonesia. Jurnal Sekuritas. ISSN (online) : 2581-2777.

Kasmir. (2017). Analisis Laporan Keuangan. PT Rajagrafindo Persada: Jakarta.

Kezia Abigail T,P. \& Liongicasia M. (2019). Pengaruh GCG, CSR, Profitabilitas dan Ukuran Perusahaan terhadap Nilai Perusahaan Jurnal Ilmiah Wahana Akuntansi Vol 14 (2) 2019, 156-169.

Lestari, N. \& Sapitri, R. C. (2016). Pengaruh intellectual capital terhadap nilai perusahaan. Jurnal Akuntasi, Ekonomi dan Manajemen Bisnis| e-ISSN: 2548-9836, 4(1), 28-33.

Lovianda, Raja Julian \& Ibrahim, Mariaty. (2018).Pengaruh Corporate Social Responsibility (CSR) dan Ukuran Perusahaan terhadap Nilai Perusahaan Pada Perusahaan Pertambangan Sub Sektor Minyak dan Gas Bumi yang Terdaftar di BURSA EFEK INDONESIA (BEI). Jurnal Online Mahasiswa Fakultas Ilmu Sosial dan Ilmu Politik. Vol. 5: Edisi II Juli - Desember 2018. Universitas Riau.

Nenggar Bestariningrum (2015). Analyzing The Effect Of Capital Structure and Firm Size On Firm Value (Case Sudy: Company That Listed In LQ-45 Index Period 2010-2014).

Ni Luh Putu Widyantari \& I Putu Yadnya (2017). Pengaruh Struktur Modal, Profitabilitas Dan Ukuran Perusahaan Terhadap Nilai Perusahaan Pada Perusahaan Food And Baverage Di Bursa Efek Indonesia. E-Jurnal Manajemen Unud, Vol. 6, No. 12, 2017: 6383-6409 Issn : 2302-8912.

Novitasari, dwi \& Drs. Muhammad Abdul Aris, M.Si (2019) Pengaruh Corporate Social Responsibility, Kebijakan Dividen, Likuiditas, Profitabilitas, Dan Ukuran Perusahaan Terhadap Nilai Perusahaan (Studi Empiris Pada Perusahaan Manufaktur Yang Terdaftar Di Bursa Efek Indonesia Tahun (20152017). Skripsi thesis, Universitas Muhammadiyah Surakarta. 
Oktrima, Bulan. (2017). Pengaruh Profitabilitas, Likuiditas , dan Struktur Modal Terhadap Nilai Perusahaan ( Studi Empiris: PT Mayora Indah, Tbk Tahun $(2011$ - 2015). Jurnal Sekuritas Vol.1, No.1/September (2017). ISSN No. 2581-2696.

Prasetyorini, Bhekti Fitri. (2013).Pengaruh Ukuran Perusahaan, Leverage, Price Earning Ratio dan Profitabilitas terhadap Nilai Perusahaan”. Jurnal Ilmu Manajemen. 1(1). Hal.186.

Puspaningsih, Abriyani \& Putri R,I. (2012). Pengaruh Corporate Social Responsibility Terhadap Nilai Perusahaan dengan Prosentase Kepemilikan Manajemen Sebagai Variabel Moderating. Jurnal Aplikasi Bisnis : Volume 13 Nomor 9, September (2012).Fakultas Ekonomi. Universitas Islam Indonesia.

Putranto, Bima. (2014). Pengaruh Pengungkapan Sustainability Report Terhadap Kinerja dan Nilai Perusahaan. Skripsi. Fakultas Ekonomika dan Bisnis. Universitas Diponegoro. Semarang.

Renly Sondakh (2019).The Effect Of Dividend Policy, Liquidity, Profitability And Firm Size On Firm Value In Financial Service Sector Industries Listed In Indonesia Stock Exchange 2015-2018 Period. Accountability Volume 08, Number 02, (2019), 91-101.

S. Setiadharma \& Machali. M. (2017). The Effect of Asset Structure and Firm Size on Firm Value with Capital Structure as Intervening Variable. Journal of Business \& Financial Affairs, Vol. 6 : 298. doi: 10.4172/2167-0234.1000298.

Sabrin, et.al. (2016). The Effect of Profitability on Firm Value in Manufacturing Company at Indonesia Stock Exchange. The International Journal of Engineering and Science (IJES). Vol.5 Issue. 10, pages PP 81-89.

Sakdiah. (2019). Pengaruh Profitabilitas, Leverage, Ukuran Perusahaan Dan Likuiditas Terhadap Kebijakan Dividen Dan Nilai Perusahaan (Studi Pada Perusahaan Sektor Manufaktur Di Bursa Efek Indonesia Periode 2013-2018). Society. Jurnal Jurusan Tadris Ips.Volume 10 , Nomor 2, Hal. 133 - 153 .Desember (2019). P-Issn: 2087-0493, E-Issn: 2715-5994.

Sigit Mareta \& Indra Dessi Yanti (2019).The Influence Of Liquidity, Leverage And Profitability On Company Value (Empirical Study On Basic Industry And Chemical Companies Listed On Indonesia Stock Exchange)". Epra International Journal Of Multidisciplinary Research (Ijmr) Peer Reviewed Journal Volume: 5 | Issue: 7 | July (2019) || Sjif Impact Factor: 5.148 Issn (Online): 2455-3662.

Suhesti Ningsih \& Shinta Permata Sari (2019). Analysis Of The Effect Of Liquidity Ratios, Solvability Ratios And Profitability Ratios On Firm Value In Go Public Companies In The Automotive And Component Sectors. International Journal Of Economics, Business And Accounting Research (Ijebar) Peer Reviewed - International Journal Vol-3, Issue-4, (2019) (IJEBAR) E-ISSN: 2614-1280 P-ISSN 2622-4771.

Sujarweni, V. \& Wiratna. (2015).Metodologi Penelitian Bisnis \& Ekonomi. Yogyakarta: Pustaka Baru Press.

Tunpornchai, Watcharapong \& Hensawang, Surang. (2018). Effects of Corporate Social Responsibility and Corporate Governance on Firm Value: Empirical Evidences of the Listed Companies on the Stock Exchange of Thailand in the Set100. PSAKU International Journal of Interdisciplinary Research, Vol.7. No.1, Available at SSRN: https://ssrn.com/abstract=3226542

Wati, L. N. (2019). Model Corporate Social Responsibility (CSR). Myria Publisher.

Yusuf, M. Y. (2017). Islamic Corporate Social Responsibility (I-CSR) Pada Lembaga Keuangan Syariah (LKS): Teori Dan Praktik. Prenada Media. 
Other References :

http://www.idx.co.id/

https://www.gaikindo.or.id/geliat-prospek-dan-tantangan-industri-otomotif-indonesia/ https://www.sahamOk.com

https://www.astra.co.id/

https://www.astra-otoparts.com/

https://www.gt-tires.com/indonesia/

https://www.indomobil.com/

https://www.indospring.co.id/

https://www.panther-wheels.net/

http://www.smsm.co.id/

http://www.indokordsa.com/

https://www.goodyear-indonesia.com/

https://www.multistrada.co.id/?lang=id 